\title{
Pengaruh pendekatan latihan dan koordinasi mata tangan terhadap ketepatan shooting peserta ekstrakurikuler basket
}

\author{
Desi Adityo Hermawan *, Hari Amirullah Rachman \\ Program Studi Ilmu Keolahragaan, Program Pascasarjana, Universitas Negeri Yogyakarta. \\ Jalan Colombo No. 1, Karangmalang, Yogyakarta, 55281, Indonesia \\ * Corresponding Author. Email: desiadityo@gmail.com
}

Received: 13 July 2018; Revised: 20 September 2018; Accepted: 21 September 2018

\begin{abstract}
Abstrak
Penelitian ini bertujuan untuk (1) mengetahui pengaruh antara pendekatan latihan teknis dan taktis dengan ketepatan shooting; (2) mengetahui pengaruh antara kemampuan motorik koordinasi mata dan tangan terhadap ketepatan shooting; (3) mengetahui interaksi pengaruh antara pendekatan latihan dan koordinasi mata dan tangan dengan ketepatan shooting. Penelitian ini merupakan penelitian eksperimen dengan menggunakan rancangan $2 \times 2$. Subjek penelitian ini yaitu siswa SMP Negeri 1 Sumpiuh dan siswa SMP Negeri 2 Sumpiuh yang mengikuti ekstrakurikuler bola basket. Teknik pengambilan sampel menggunakan teknik purposive random sampling dengan total responden sebanyak 20 orang. Instrumen pengumpulan data menggunakan tes pengukuran. Analisis data menggunakan ANOVA dua jalur (ANOVA two-way). Hasil penelitian menunjukkan (1) ada perbedaan yang signifikan pendekatan teknis, dan taktis mempengaruhi ketepatan shooting dalam permainan bola basket; (2) ada perbedaan pengaruh yang signifikan kemampuan motorik koordinasi mata dan tangan dengan ketepatan shooting dalam permainan bola basket; (3) ada interaksi yang signifikan antara pendekatan latihan dan koordinasi mata tangan dengan ketepatan shooting dalam permainan bola basket.
\end{abstract}

Kata Kunci: pendekatan latihan, koordinasi mata tangan, ketepatan shooting

\section{The influence of training approach and eyes-and-hands coordination on shooting accuracy in the participant's basket extracurricular activity}

\begin{abstract}
The study was conducted in order to: (1) identify the influence of technical and tactical practice on shooting accuracy; (2) identify the influence of motoric capacity within the eyes-and-hands coordination on shooting accuracy; and (3) identify the influence of training approach and eyes-andhands coordination on shooting accuracy. The study was a $2 x 2$ experiment and the subjects in the study were the students of Negeri 1 Sumpiuh State Junior High School who attended the basketball extracurricular activity. The samples in the selected by means of purposive random sampling technique with total number of respondents 20 people. In gathering the data, a measurement test was administered among the students and the data were analysed by using two-way ANOVA. The results of the study show that: (1) the technical and tactical practice has significant influence on shooting accuracy within the basketball game; (2) the motoric capacity within the eyes-and-hands coordination has significant influence on shooting accuracy within the basketball game; and (3) the eyes-and-hands training and coordination approach has significant influence on shooting accuracy within the basketball game.
\end{abstract}

Keywords: training approach, eyes-and-hands coordination, shooting accuracy

How to Cite: Hermawan, D., \& Rachman, H. (2018). Pengaruh pendekatan latihan dan koordinasi mata tangan terhadap ketepatan shooting peserta ekstrakurikuler basket. Jurnal Keolahragaan, 6(2), 100-109. doi:https://doi.org/10.21831/jk.v0i0.20349

https://doi.org/10.21831/jk.v0i0.20349 


\section{PENDAHULUAN}

Pendidikan merupakan salah satu kebutuhan yang sangat penting bagi setiap orang, karena pendidikan menjadikan pribadi seseorang mengerti akan harkat dan martabat dari diri pribadi mereka sendiri. Maksud dan tujuan dari pendidikan untuk mengembangkan potensi serta bakat yang dimiliki setiap orang, apabila tidak dikembangkan dengan baik potensi dan bakat yang dimilki tidak akan berkembang. Melalui proses pendidikan untuk mengembangkan potensi dan bakat, sesorang dapat mewujudkan serta mengembangkan bakatnya tersebut dengan maksimal sehingga dapat dirasakan hasilnya untuk diri sediri dan bersama.

Pendidikan jasmani mempunyai tujuan menekankan pada aspek pendidikan yang bersifat menyeluruh, seperti kesehatan, kebugaran jasmani, keterampilan berfikir kritis, stabilitas emosional, keterampilan sosial, penalaran dan tindakan moral, yang merupakan tujuan pendidikan pada umumnya (Rachman, 2009, p. 20). Selain dapat meningkatkan kebugaran jasmani mata pelajaran pendidikan jasmani memiliki banyak manfaat lain salah satunya sebagai penunjang potensi dan bakat siswa, pembentukan karakter bagi siswa agar sehat jasmani dan rohani, mempunyai sikap sportif, bertanggung jawab, dan meningkatkan rasa percaya diri pada diri siswa. Sementara tujuan lain dari pendidikan jasmani di sekolah adalah (1) mengembangkan pengetahuan dan keterampilan yang berkaitan dengan aktivitas jasmani, perkembangan sosial, (2) mengembangkan kepercayaan diri dan kemampuan untuk menguasai keterampilan gerak dasar yang mendorong partisipasinya dalam aneka aktivitas jasmani, (3) memperoleh dan mempertahankan derajat kebugaran jasmani yang optimal untuk melaksanakan tugas sehari-hari secara efisien dan terkendali, (4) mengembangkan nilai-nilai pribadi melalui partisipasi dalam aktivitas jasmani baik secara kelompok maupun perorangan, (5) berpartisipasi dalam aktivitas jasmani yang dapat mengembangkan keterampilan sosial yang memungkinkan siswa berfungsi secara efektif dalam hubungan antara orang, dan (6) menikmati kesenangan dan keriangan melalui aktifitas jasmani, termasuk permainan olahraga (Husdarta, 2011; Jatmika, 2005). Dengan demikian pendidikan jasmani di sekolah harus benarbenar dilakukan dengan sebaik mugkin dan terarah, agar manfaat serta tujuannya dapat tercapai dengan maksimal, dan nilai-nilai penting yang terkandung dalam pendidikan jasmani dapat disampaikan pada siswa dengan baik. Peran tenaga pengajar atau guru dalam pendidikan jasmani di sekolah adalah salah satu kunci penting dalam menyampaikan manfaat dan tujuan dari pendidikan tersebut, diperlukan peran aktif dan bimbingan guru untuk bisa memberikan serta menyampaikan nilai-nilai penting dari tujuan dan manfaat pendidikan jasmani.

Sekolah sebagai tempat terselengaranya proses belajar mengajar yang meliputi kegiatan intrakurikuler dan ekstrakurikuler. Kegiatan intrakurikuler adalah proses kegiatan belajar mengajar (KBM) yang alokasi waktunya sudah diatur berdasarkan kurikulum yang sudah ada. Sedangkan ekstrakurikuler sendiri adalah kegiatan yang dilakukan diluar dari KBM, dan waktu pelaksanaannya diluar dari jam sekolah, biasa dilaksanakan setelah selesai jam sekolah atau pulang sekolah. Kegiatan ektrakurikuler bertujuan sebagai wadah pembinaan bagi siswa di sekolah agar dapat menyalurkan serta mengembangkan potensi dan bakat yang dimiliki di luar dari kegiatan intrakurikuler, berdasarkan minat dan kemampuan dari setiap siswa.

Ekstrakurikuler dapat dikelompokan menjadi tiga kelompok kegiatan yaitu ekstrakurikuler yang berhubungan dengan kesenian, ekstrakurikuler yang berkaitan dengan olahraga, dan ekstrakurikuler yang bersifat non seni dan olahraga. Salah satu ekstrakurikuler yang paling banyak diminati para siswa di sekolah adalah ekstrakulikuler yang berhubungan dengan kesenian dan olahraga. Ekstrakurikuler olahraga sendiri adalah wadah bagi siswa untuk menyalurkan minat dan bakat pada salah satu cabang olahraga tertentu, dengan tujuan meningkatkan serta mengasah kemampuan dan keterampilan dalam olahraga. Menurut Departemen Pendidikan dan Kebudayaan Republik Indonesia (1994, p.6) kegiatan ekstrakurikuler adalah kegiatan olahraga yang dilakukan di luar jam pembelajaran tatap muka, dilaksanakan untuk lebih memperluas wawasan atau kemampuan peningkatan dan penerapan nilai pengetahuan dan kemampuan olahraga.

Olahraga bola basket adalah salah satu ekstrakurikuler olahraga yang paling banyak dipilih oleh para siswa khususnya siswa sekolah menengah pertama (SMP), pemilihan bola basket oleh para siswa dikarenakan dalam permainan bola basket sendiri dianggap lebih seru dan menantang. Meskipun tidak jauh berbeda dengan olahraga lain seperti sepak bola dan bola voli, akan tetapi minat siswa pada cabang olahraga bola basket sangat banyak terutama dari siswa perempuan. Cabang olahraga bola basket adalah 
satu mata pelajaran dalam pendidikan jasmani yang dilaksanakan dan diajarkan kepada siswa di sekolah-sekolah. Dalam proses belajar dan berlatih bola basket selain bertujuan meningkatkan kebugaran jasmani para siswa harus memiliki kekuatan, kecepatan, kelincahan, kelentukan, ketepatan, daya tahan serta koordinasi yang baik. Tujuan penting lain melalui kegiatan belajar bola basket seperti melatih kedisiplinan, mendidik watak, dan meningkatkan prestasi baik dalam kegiatan intrakurikuler maupun ekstrakurikuler.

Permainan bola basket adalah salah satu permainan bola besar yang dimainkan oleh dua tim atau regu beranggotakan lima orang dalam setiap tim, mencetak point dengan cara memasukkan bola ke dalam keranjang lawan. Bola basket membutuhkan integrasi bakat individu yang tidak menjadi egois melainkan menekankan kerjasama (Wissel, 2011, p. 7). Dalam permainan bola basket kerjasama satu tim merupakan aspek yang sangat penting dan seorang pemain bola basket tidak boleh egois, dengan demikian dalam satu tim dibutuhkan kekompakkan serta kerja sama tim yang tinggi sebagai kekuatan dari tim tersebut.

Selain kekompakan dan kerja sama tim yang baik penguasan teknik dasar dalam permainan bola basket juga penting untuk menunjang kualitas perminan bola basket, ada beberapa teknik dasar yang harus dikuasai dalam permainan bola basket antara lain menembak (shooting), mengoper bola (passing), menggiring bola (dribble), dan menangkap bola (catching). Shooting atau menembakan bola dalam permainan bola basket adalah salah satu teknik yang sangat penting dan wajib dikuasi oleh seluruh pemain bola basket. Dalam permainan bola basket menembak merupakan unsur penting dalam pertandingan karena kemenangan ditentukan oleh banyaknya bola yang masuk ke dalam ring atau keranjang (Mahardika, 2014, p. 3). Dengan demikian dalam pertandingan bola basket shooting bola untuk memperoleh poin tambahan dengan cara menembak atau shooting bola ke keranjang lawan dengan tepat sasaran dan sebanyak-banyaknya adalah aspek yang sangat penting, sehingga diperlukan latihan yang ekstra untuk melatih ketepatan melakukan shooting dalam permainan bola basket.

Pemilihan bola basket sebagai salah satu cabang olahraga favorit pilihan siswa dan memiliki jumlah peminat yang banyak dapat dilihat dari setiap sekolah yang ada baik sekolah menengah pertama (SMP) maupun sekolah menengah atas (SMA) yang memiliki kegiatan ekstrakurikuler bola basket. Begitu juga halnya dengan SMP yang berada di kecamatan Sumpiuh, kabupaten Banyumas, yaitu SMP Negeri 1 Sumpiuh dan SMP Negeri 2 Sumpiuh, jumlah siswa peminat ekstrakurikuler bola basket cukup banyak. Akan tetapi masih ada beberapa kendala yang dihadapi oleh siswa peserta ekstrakurikuler maupun pelatih, seperti sarana penunjang untuk bermain bola basket dirasa masih kurang mendukung sehingga akan mempengaruhi minat latihan dan semangat siswa dalam bermain bola basket.

Dalam kaitanya dengan permainan bola basket, selain sarana pendukung dalam bermain bola basket yang tidak kalah penting adalah pemakaian metode latihan yang diberikan. Pemakaian metode latihan yang tepat, efektif, dan efisien sangatlah berpengaruh terhadap keterampilan dan hasil bermain bola basket para siswa, kerena hal tersebut berhubungan dengan tingkat kompleksitas gerak yang terdapat dalam permainan bola basket tersebut. Maka dari itu diperlukan pemilihan dan pemakaian metode latihan yang sesuai dengan kebutuhan serta melihat karakteristik yang dimiliki masingmasing siswa agar tujuan dari keterampilan bermain bola basket dapat dikuasai dengan baik dan benar.

Berdasarkan pengalaman dan pengamatan yang telah dilakukan di lapangan, guru atau pelatih ekstrakurikuler bola basket di sekolah belum secara optimal dapat meningkatkan keterampilan bermain bola basket para siswa, diantaranya terjadi karena karakteristik siswa yang berbeda-beda, seperti kondisi fisik masingmasing siswa, kompleksitas gerak permainan dan kurangnya pemahaman guru atau pelatih dalam pemakaian metode latihan yang tepat. Pemilihan dan pemakaian metode latihan diharapkan bisa memberikan pengaruh yang besar untuk kemajuan permainan bola basket, sehingga siswa dapat bermain dengan baik dan benar. Diperlukan kreatifitas yang tinggi dari guru atau pelatih ekstrakurikuler bola basket dalam memilih dan memakai metode latihan yang tepat, akan tetapi dalam prakteknya masih banyak latihan yang belum terprogram dengan baik.

Metode latihan yang tepat akan memudahkan siswa dalam berlatih dan tujuan latihan yang telah ditetapkan dapat tercapai dengan maksimal. Adapun pendekatan latihan yang biasa digunakan untuk meningkatkan kemampuan permainan bola basket para siswa yaitu pendekatan teknis dan taktis. Dari kedua pendekatan tersebut dapat diketahui bahwa masing-masing memiliki karak- 
teristik dan tujuan yang berbeda dan belum diketahui pendekatan mana yang lebih tepat dan efektif untuk meningkatkan keterampilan bermain bola basket. Kelemahan paling menonjol dalam bermain bola basket adalah mengoper bola (passing), mengiring bola (drible), dan menembak bola (shooting) ke arah ring atau keranjang. Dari setiap pertandingan masih banyak yang melakukan kesalahan sehingga kelemahan tersebut mudah dibaca oleh lawan. Dengan kelemahan tersebut guru atau pelatih ekstrakurikuler bola basket dituntut harus berusaha lebih keras untuk membenahi penguasaan teknik dasar bermain bola basket dengan baik dan benar, inovasi dan kreatifitas guru atau pelatih sangat diperlukan dalam menentukan serta memilih metode latihan yang tepat sesuai dengan karakteristik dan tujuan dari materi latihan yang akan diberikan. Pemilihan dan pemakaian metode latihan tetap mempertimbangkan keefektifan waktu, biaya, energi, ketersediaan fasilitas dan alat penunjang latihan.

Pendekatan latihan yang sering digunakan dalam pelaksanaan kegiatan ekstrakulikuler bola basket adalah pendekatan latihan teknis yang mayoritas digunakan oleh para pelatih. Menurut Sagala (2009, p. 21) menjelaskan bahwa pendekatan teknis adalah pendekatan latihan, atau pedekatan training yang merupakan suatu cara mengajar yang baik untuk menanamkan kebiasaan-kebiasaan tertentu. Juga sebagai sarana untuk memperoleh suatu ketangkasan, ketepatan, kesempatan, dan keterampilan. Pendekatan latihan teknis dalam pelaksanaannya lebih menekankan pada melatih keterampilan teknik atau beberapa teknik dasar. Sementara makna dan pemahaman dari permainan itu sendiri sering terabaikan, dengan pola pendekatan teknis pelatih sering menghabiskan waktu hanya untuk mempelajari teknik dasar, sehingga waktu yang dipakai kurang efektif, dan terkesan model pendekatan semacam ini membosankan, kurang menarik, dan monoton. Selain itu masih banyak siswa cenderung kurang mampu untuk mengaplikasikan beberapa teknik dasar yang telah dikuasai dengan pola bermain bola basket secara utuh.

Sementara itu berbeda dengan model pendekatan teknis yang lebih menekankan pada penguasaan teknik dasar, model atau pola pendekatan taktis sendiri diaplikasikan melalui aktivitas bermain dan penguasaan teknik dasar dilakukan bersamaan dengan pola bermain. Menurut Subroto (2009, p. 5) tujuan pendekatan taktis adalah untuk meningkatkan kesadaran siswa tentang konsep bermain melalui penerapan teknik yang tepat sesuai dengan masalah atau situasi dalam permainan. Kaitannya dengan permainan bola basket, pendekatan taktis dimaksudkan mendorong siswa agar bisa memecahkan masalah taktis dalam permainan bola basket, serta bisa menerapkan keterampilan teknik dasar dalam situasi permainan bola basket yang sebenarnya tanpa ada penekanan. Pendekatan taktis sendiri pada dasarnya mengajarkan bagaimana siswa agar dapat memahami konsep bermain bola basket yang kemudian disesuaikan dengan kebutuhan untuk meningkatkan mutu permainan bola basket.

Berdasarkan pengamatan di lapangan ada beberpa permasalaan yang dihadapi dua sekolah yaitu SMP 1 Sumpiuh dan SMP 2 Sumpiuh yang relatif sama. Jumlah peserta ekstrakurikuler bola basket yang banyak tidak diimbangi dengan fasilitas yang ada, seperti 40 anak peserta ekstrakurikuler bola basket harus latihan dengan menggunakan 3 bola, kondisi lapangan yang kurang mendukung seperti garis lapangan yang tidak jelas terlihat, dan ada beberapa ring yang rusak sehingga tidak menutup kemungkinan justru akan membahayakan siswa dalam bermaian bola basket. Masalah yang muncul di lapangan memiliki pengaruh yang sangat besar terhadap minat dan semangat latihan siswa, sehingga hasil permainan bola basket siswa juga akan menurun.

Permasalahan lain yang dihadapi SMP 1 Sumpiuh dan SMP 2 Sumpiuh adalah tidak adanya tenaga pelatih bola basket yang berlisensi atau pelatih yang benar-benar kompeten dalam cabang olahraga bola basket untuk mendampingi siswa dalam kegiatan ekstrakurikuler. Bahkan ekstrakurikuler bola basket yang berlangsung ditangani oleh guru mata pelajaran dan bukan guru olahraga, hal ini tentunya menjadi suatu masalah karena akan berakibat dengan pemilihan dan pemakaian program latihan yang akan diberikan pada siswa. Pemilihan dan pemakaian program latihan yang kurang sesuai dengan kebutuhan dan hanya menekankan pada teknik dasar akan berakibat pada tingkat kompleksitas gerak siswa dalam bermainan bola basket, yaitu tidak leluasanya siswa dan masih terlihat kaku dalam bergerak. Salah satunya gerakan siswa pada saat menggiring bola sambil berlari, kemudian melakukan tembakan atau shooting ke arah ring ternyata masih banyak yang tidak tepat pada sasaran, padahal dalam permainan bola basket sendiri tidak hanya mengandalkan kecepatan dan ketepatan melainkan koordinasi mata dan tangan yang tinggi atau baik juga sangat penting. Koordinasi mata dan tangan memiliki peran yang sangat besar dalam setiap aktifitas 
gerak dalam olahraga, terutama yang melibatkan fungsi tangan dan pengamatan terhadap suatu obyek. Kedua anggota tubuh yaitu mata dan tangan bila melaksanakan fungsinya untuk suatu tugas bersama-sama dengan yang lain akan bekerja secara terpadu (Supriyanto, 2013, p. 589).

Berkaitan dengan penelitian-penelitian terdahulu, peneliti bermaksud ingin menggali lagi penelitian yang sejalan dan melengkapi penelitian terdahulu. Di dalamnya akan meninjau pada aspek penyelesaian akhir dalam permainan bola basket seperti shooting, diperlukan koordinasi mata tangan yang baik agar ketepatan dari shooting yang dilakukan dapat tepat pada sasaran, sehingga para siswa atau peserta didik mampu menguasai keterampilan bermain bola basket dengan baik dan benar.

Menurut peneliti bahwa model pendekatan latihan teknis dan taktis belum cukup untuk menunjang secara maksimal terhadap keterampilan bermain bola basket. Artinya siswa atau peserta ekstrakrikuler bola basket juga harus memiliki kemampuan motorik, seperti koordinasi mata dan tangan yang baik. Sehingga peneliti berfikiran bahwa siswa yang memiliki kemampuan koordinasi mata tangan yang baik dan dikaitkan dengan pendekatan latihan teknis dan taktis hasilnya akan lebih optimal.

Dari uraian permasalahan yang telah dijelaskan, maka peneliti tertarik untuk melihat pengaruh pendekatan latihan teknis dan taktis terhadap hasil latihan keterampilan bermain bola basket dikaitkan dengan koordinasi mata tangan yang dimiliki oleh siswa.

\section{METODE}

Jenis penelitian yang digunakan dalam penelitian ini adalah jenis eksperimen dengan menggunakan rancangan $2 \times 2$ yaitu suatu eksperimen faktorial yang menyangkut dua faktor, yang terdiri atas dua taraf dengan menggunakan test awal (pre-test) dan tes akhir (post-test).

Waktu yang dilakukan dalam peneitian ini dimulai pada bulan November 2017, sedangkan tempat penelitian berlangsung di SMP Negeri 1 Sumpiuh, dan SMP Negeri 2 Sumpiuh, yang berada di Kecamatan Sumpiuh, Kabupaten Banyumas, Jawa Tengah, Indonesia.

Subjek dalam penelitian ini berjumlah 20 siswa yang kemudian digolongkan menjadi 4 kelompok yang diacak dengan teknik random sampling, yang kemudian diurutkan berdasarkan ranking dari koordinasi mata tangan tinggi sampai terendah.
Penelitian ini memakai desain eksperimen dua faktor dan dua level, faktor pertama variabel manipulatif adalah pendekatan latihan dan faktor kedua variabel atributif yaitu koordinasi matatangan. Pendekatan latihan disini terdiri dari pendekatan teknis dan pendekatan taktis, sedangkan variabel atributif terdiri dari koordinasi matatangan tinggi dan koordinasi mata-tangan rendah.

Tabel 1. Rancangan Faktorial 2x2

\begin{tabular}{|c|c|c|}
\hline $\begin{array}{l}\text { Pendekatan } \\
\text { Latihan } \\
\text { Koordinasi } \\
\text { Mata Tangan } \\
\text { (B) }\end{array}$ & $\begin{array}{l}\text { Teknis } \\
\text { (A1) }\end{array}$ & $\begin{array}{c}\text { Taktis } \\
\text { (A2) }\end{array}$ \\
\hline $\begin{array}{c}\text { Tinggi (B1) } \\
\text { Rendah (B2) }\end{array}$ & $\begin{array}{l}\text { A1.B1 } \\
\text { A1.B2 }\end{array}$ & $\begin{array}{l}\text { A2.B1 } \\
\text { A2.B2 }\end{array}$ \\
\hline
\end{tabular}

Keterangan Tabel:

A1: Pendekatan teknis.

A2: Pedekatan taktis.

B1: Koordinasi mata tangan tinggi.

B2: Koordinasi mata tangan rendah.

A1.B1: Kelompok latihan pendekatan teknis dengan koordinasi mata tangan tinggi.

A2.B1: Kelompok latihan pendekatan taktis dengan koordinasi mata tangan tinggi.

A1.B2: Kelompok latihan pendekatan teknis dengan koordinasi mata tangan rendah.

A2.B2: Kelompok latihan pendekatan taktis dengan koordinasi mata tangan rendah.

Jenis data yang diperoleh dalam penelitian ini adalah data kuantitatif, dan data tersebut diperoleh dari pengukuran tes koordinasi mata tangan, dan tes ketepatan shooting bola basket. Dalam pelaksanaan tes pengukuran koordinasi mata tangan yaitu menggunakan instrumen tes dengan cara melakukan lempar tangkap bola tenis pada tembok sasaran dengan jarak tembak sejauh 2,5 meter yang kemudian bola ditangkap kembali. Siswa diberikan 10 kali kesempatan dalam melempar. Peralatan yang dibutuhkan untuk melakukan tes koordinasi mata dan tangan antara lain: bidang sasaran yang ditempelkan pada tembok, pita atau kapur sebagai garis batas lemparan, bola tenis, peluit.

Sedangkan dalam tes ketepatan shooting dalam bola basket yaitu menggunakan instrumen menembak bola ke arah ring atau free throw selama satu menit. Dalam pelaksanaan tes shooting selama satu menit bertujuan untuk mengukur seberapa akurat dan tepat dalam melakukan tembakan ke arah ring atau keranjang. Petunjuk pelaksanaan tes shooting siswa bersiap di posisi free throw kemudian menunggu aba-aba dari pelatih dengan cara meniup peluit yang kemudian siswa melakukan tembakan ke arah ring seba- 
nyak mungkin selama 1 menit, dan nilai yang diperoleh dari banyaknya bola yang masuk pada keranjang atau ring. Peralatan yang dibutuhkan dalam pelaksanaan tes ketepatan shooting yaitu: bola basket, stopwatch, peluit.

Instrumen dalam penelitian ini yaitu tes koordinasi mata tangan dan tes ketepatan shooting bola basket. Validitas tes koordinasi mata tangan sebesar 0,976, dan tes kemampuan shooting bola basket sebesar 0,864 . Sedangkan reliabilitas tes koordinasi mata tangan sebesar 0,987, dan tes ketepatan shooting bola basket sebesar 0,927 .

Teknik analisis data yang digunakan dalam penelitian ini menggunakan ANOVA dua jalur (ANOVA two-way) pada taraf signifikansi $\alpha=$ 0,05 . Mengingat analisis data penelitian dilakukan dengan menggunakan ANOVA, maka sebelum sampai pada pemanfaatan ANOVA dua jalur (ANOVA two-way) maka perlu dilakukan uji persyaratan yaitu meliputi uji normalitas, dan uji homogenitas varians.

\section{HASIL DAN PEMBAHASAN}

Data penelitian ini merupakan hasil pengukuran terhadap pengaruh pendekatan latihan (teknis dan taktis) dan koordinasi mata dan tangan terhadap ketepatan shooting. Pengukuran data dilakukan sebanyak dua kali yaitu sebelum perlakuan (pretest) dan sesudah perlakuan (posttest) pada masing-masing kelompok yaitu kelompok pendekatan teknis-koordinasi mata tangan tinggi, pendekatan taktis-koordinasi mata tangan tinggi, pendekatan teknis-koordinasi mata tangan rendah dan pendekatan taktis-koordinasi mata tangan rendah.
Berdasarkan Tabel 2 diketahui nilai rerata ketepatan shooting saat pretest pada kelompok pendekatan teknis-koordinasi tinggi $\left(\mathrm{A}_{1} \mathrm{~B}_{1}\right)$ sebesar 6,80, dan nilai rerata pada saat posttest sebesar 13,20. Pada kelompok pendekatan tekniskoordinasi tinggi terjadi peningkatan ketepatan shooting sebesar 6,40. Hasil analisis diketahui nilai rerata ketepatan shooting saat pretest pada kelompok pendekatan taktis-koordinasi tinggi $\left(\mathrm{A}_{2} \mathrm{~B}_{1}\right)$ sebesar 6,20, dan nilai rerata pada saat posttest sebesar 15,00. Pada kelompok pendekatan taktis-koordinasi tinggi terjadi peningkatan ketepatan shooting sebesar 8,80.

Hasil analisis diketahui nilai rerata ketepatan shooting saat pretest pada kelompok pendekatan teknis-koordinasi rendah $\left(\mathrm{A}_{1} \mathrm{~B}_{2}\right)$ sebesar 8,80 , dan nilai rerata pada saat posttest sebesar 9,00. Pada kelompok pendekatan teknis-koordinasi rendah terjadi peningkatan ketepatan shooting sebesar 0,20. Hasil analisis nilai rerata ketepatan shooting saat pretest pada kelompok pendekatan taktis-koordinasi rendah $\left(\mathrm{A}_{2} \mathrm{~B}_{2}\right)$ sebesar 8,00, dan nilai rerata pada saat posttest sebesar 14,80. Pada kelompok pendekatan taktiskoordinasi tinggi terjadi peningkatan ketepatan shooting sebesar 6,80.

Perbandingan peningkatan rerata ketepatan shooting pada masing-masing kelompok perlakuan dapat dilihat pada Gambar 1. Berdasarkan Gambar 1 dapat diketahui bahwa peningkatan ketepatan shooting paling besar adalah pada kelompok pendekatan taktis-koordinasi mata tangan tinggi $\left(\mathrm{A}_{2} \mathrm{~B}_{1}\right)$ yaitu sebesar 8,8 sedangkan peningkatan paling rendah pada kelompok pendekatan teknis-koordinasi mata tangan rendah $\left(\mathrm{A}_{1} \mathrm{~B}_{2}\right)$ yaitu sebesar 0,2 .

Tabel 2. Perbandingan Nilai Rerata Masing-Masing Kelompok Perlakuan

\begin{tabular}{clccc}
\hline No. & \multicolumn{1}{c}{ Kelompok Perlakuan } & Rerata Pretest & Rerata Posttest & Peningkatan \\
\hline 1. & Teknis-koordinasi tinggi $\left(\mathrm{A}_{1} \mathrm{~B}_{1}\right)$ & 6,80 & 13,20 & 6,40 \\
2. & Taktis-koordinasi tinggi $\left(\mathrm{A}_{2} \mathrm{~B}_{1}\right)$ & 6,20 & 15,00 & 8,80 \\
3. & Teknis-koordinasi rendah $\left(\mathrm{A}_{1} \mathrm{~B}_{2}\right)$ & 8,80 & 9,00 & 0,20 \\
4. & Taktis-koordinasi rendah $\left(\mathrm{A}_{2} \mathrm{~B}_{2}\right)$ & 8,00 & 14,80 & 6,80 \\
\hline
\end{tabular}

Tabel 3. Hasil uji Normalitas Data

\begin{tabular}{ccccc}
\hline Kelompok & Ketepatan Shooting & KSZ & Sig. & Keterangan \\
\hline Teknis-Koordinasi Tinggi $\left(\mathrm{A}_{1} \mathrm{~B}_{1}\right)$ & Pretest & 0,780 & 0,577 & Normal \\
& Posttest & 0,316 & 1,000 & Normal \\
Taktis-Koordinasi Tinggi $\left(\mathrm{A}_{2} \mathrm{~B}_{1}\right)$ & Pretest & 0,495 & 0,967 & Normal \\
& Posttest & 0,578 & 0,892 & Normal \\
Teknis-Koordinasi Rendah $\left(\mathrm{A}_{1} \mathrm{~B}_{2}\right)$ & Pretest & 0,779 & 0,578 & Normal \\
& Posttest & 0,711 & 0,692 & Normal \\
Taktis-Koordinasi Rendah $\left(\mathrm{A}_{2} \mathrm{~B}_{2}\right)$ & Pretest & 0,374 & 0,999 & Normal \\
& Posttest & 0,316 & 1,000 & Normal \\
\hline
\end{tabular}


Jurnal Keolahragaan 6 (2), 2018 - 106

Desi Adityo Hermawan, Hari Amirullah Rachman

Tabel 4. Uji Homogenitas Data

\begin{tabular}{|c|c|c|c|c|c|c|}
\hline \multirow{2}{*}{ Data } & \multirow{2}{*}{ Kelompok } & \multicolumn{2}{|c|}{ Pretest } & \multicolumn{2}{|c|}{ Posttest } & \multirow{2}{*}{ Ket. } \\
\hline & & F Hitung & Sig. & F Hitung & Sig. & \\
\hline Ketepatan Shooting & $\begin{array}{l}\left(\mathrm{A}_{1} \mathrm{~B}_{1}\right) \\
\left(\mathrm{A}_{2} \mathrm{~B}_{1}\right) \\
\left(\mathrm{A}_{1} \mathrm{~B}_{2}\right) \\
\left(\mathrm{A}_{2} \mathrm{~B}_{2}\right)\end{array}$ & 1,267 & 0,319 & 0,522 & 0,673 & Homogen \\
\hline
\end{tabular}

Tabel 5. Hasil Analisis Two Way Anava

\begin{tabular}{lccc}
\hline \multicolumn{1}{c}{ Perlakuan } & F Hitung & Sig. & Ket. \\
\hline Pendekatan Latihan & 17,610 & 0,001 & Signifikan \\
Koordinasi Mata Tangan & 5,902 & 0,027 & Signifikan \\
Interaksi Pendekatan Latihan-Koordinasi Mata Tangan & 4,878 & 0,042 & Signifikan \\
\hline
\end{tabular}

Tabel 6. Hasil Uji Tukey

\begin{tabular}{cccc}
\hline Kelompok & Kelompok & Mean Difference & Sig. \\
\hline \multirow{3}{*}{ Teknis-tinggi } & Taktis-tinggi & $-1,28$ & 0,514 \\
& Teknis-rendah & 4,20 & 0,022 \\
& Taktis-rendah & $-1,60$ & 0,606 \\
\multirow{3}{*}{ Taktis-tinggi } & Teknis-tinggi & 1,80 & 0,514 \\
& Teknis-rendah & 6,00 & 0,001 \\
& Taktis-rendah & 0,20 & 0,999 \\
\multirow{3}{*}{ Teknis-rendah } & Teknis-tinggi & $-4,20$ & 0,022 \\
& Taktis-tinggi & $-6,00$ & 0,001 \\
& Taktis-rendah & $-5,80$ & 0,002 \\
Taktis-rendah & Teknis-tinggi & 1,60 & 0,606 \\
& Taktis-tinggi & $-0,20$ & 0,999 \\
& Taktis-rendah & 5,80 & 0,002 \\
\hline
\end{tabular}

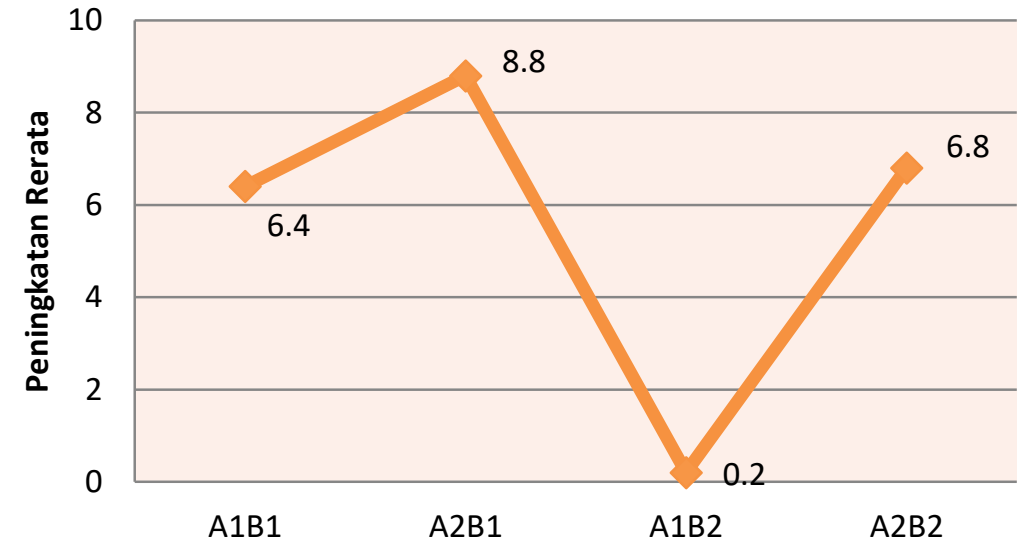

Gambar 1. Diagram Peningkatan Rerata Ketepatan Shooting

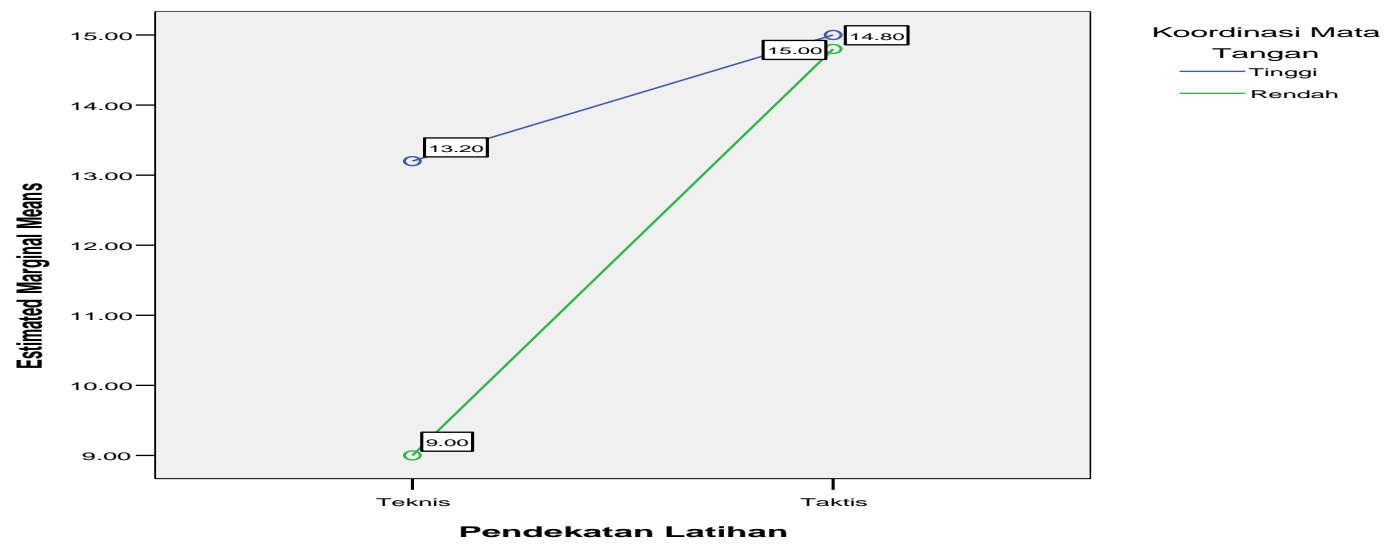

Gambar 2. Interaksi Pendekatan Latihan dan Koordinasi Mata Tangan. 
Uji Normalitas

Uji normalitas data dilakukan menggunakan Kolmogorov Smirnov Z. Pembacaan hasil data dikatakan normal apabila p value (Sig.) $>0,05$. Hasil uji normalitas ditunjukkan pada Tabel 3. Tabel 3 menunjukan hasil perhitungan normalitas data kelompok pendekatan tekniskoordinasi tinggi $\left(\mathrm{A}^{1} \mathrm{~B}^{1}\right)$ pada saat pretest diperoleh nilai KSZ sebesar 0,780 dan nilai signifikansinya sebesar 0,577. Sedangan dalam data posttest diperoleh nilai KSZ sebesar 0,316 dan nilai signifikansi sebesar 1,000 . Hasil pendekatan taktis-koordinasi tinggi $\left(\mathrm{A}_{2} \mathrm{~B}_{1}\right)$ pada saat pretest diperoleh nilai KSZ sebesar 0,495 dan nilai signifikansi sebesar 0,967. Pada data posttest diperoleh nilai KSZ sebesar 0,578 dan nilai signifikansi sebesar 0,892.

Hasil perhitungan normalitas data kelompok pendekatan teknis-koordinasi rendah $\left(\mathrm{A}_{1} \mathrm{~B}_{2}\right)$ pada saat pretest diperoleh nilai $\mathrm{KSZ}$ sebesar 0,779 dan nilai signifikansi sebesar 0,578. Pada data posttest diperoleh nilai KSZ sebesar 0,711 dan nilai signifikansi sebesar 0,692 . Perhitungan normalitas data kelompok pendekatan taktiskoordinasi rendah $\left(\mathrm{A}_{2} \mathrm{~B}_{2}\right)$ pada saat pretest diperoleh nilai KSZ sebesar 0,374 dan nilai signifikansi sebesar 0,999. Pada data posttest diperoleh nilai KSZ sebesar 0,316 dan nilai signifikansi sebesar 1,000. Hasil analisis uji normalitas pada data pretest dan posttest yang diperoleh pada masing-masing kelompok perlakuan didapatkan nilai signifikansi lebih besar dari 0,05 ( $>>0,05)$, maka dapat dinyatakan bahwa data penelitian ini berdistribusi normal, dan penelitian ini memenuhi kriteria kurva kenormalan data sebagai syarat analisis statistik parametrik

\section{Uji Homogenitas}

Untuk menguji homogenitas kesamaan varians antara data kepada kelompok perlakukan menggunakan uji-F, yaitu membandingkan varians terbesar dengan varians terkecil. Hasil uji homogenitas ditunjukkan pada Tabel 4.

Berdasarkan Tabel 4 hasil uji homogenitas, data pretest pada tabel diperoleh nilai $\mathrm{F}$ hitung sebesar 1,267 dengan nilai signifikansi sebesar 0,319 , dan data posttest diperoleh nilai $\mathrm{F}$ hitung sebesar 0,522 dengan nilai signifikansi sebesar 0,673. Dengan demikian apabila nilai signifikansi lebih besar dari 0,05 ( $p>0,05)$, maka dapat dinyatakan bahwa data pretest dan posttest ketepatan shooting pada masing-masing kelompok perlakukan adalah homogen, yang berarti terdapat kesamaan varians antara data posttest dan pada empat kelompok yang diberikan perlakuan sehingga data tersebut dianggap memenuhi syarat untuk analisis statistik parametrik.

\section{Pengujian Hipotesis}

Penelitian ini mengajukan 3 hipotesis penelitian. Pengujian hipotesis pada penelitian ini menggunakan uji Two Way Anova yang terdapat pada Tabel 5.

\section{Pengujian Hipotesis Pertama}

Hipotesis 1 dalam penelitian ini adalah "Ada perbedaan yang signifikan pendekatan teknis, dan taktis mempengaruhi ketepatan shooting dalam permainan bola basket". Berdasarkan hasil analisis Two Way Anova pada variabel pendekatan diperoleh nilai $F$ hitung sebesar 17,610 dengan nilai signifikansi sebesar 0,001 . Oleh karena nilai signifikansi sebesar 0,001 lebih kecil dari 0,05 $(\mathrm{p}<0,05)$, maka disimpulkan ada perbedaan yang signifikan pendekatan teknis, dan taktis mempengaruhi ketepatan shooting dalam permainan bola basket, sehingga hipotesis pertama diterima.

\section{Pengujian Hipotesis Kedua}

Hipotesis 2 penelitian ini berisi "Ada perbedaan pengaruh yang signifikan kemampuan motorik koordinasi mata dan tangan dengan ketepatan shooting dalam permainan bola basket". Berdasarkan hasil analisis Two Way Anova pada variabel koordinasi mata tangan diperoleh nilai $\mathrm{F}$ hitung sebesar 5,902 dengan nilai signifikansi sebesar 0,027 . Oleh karena nilai signifikansi sebesar 0,027 lebih kecil dari 0,05 ( $p<0,05)$, maka dapat disimpulkan ada perbedaan pengaruh yang signifikan kemampuan motorik koordinasi mata dan tangan dengan ketepatan shooting dalam permainan bola basket, sehingga hipotesis kedua penelitian ini dapat diterima.

\section{Pengujian Hipotesis Ketiga}

Hipotesis 3 dalam penelitian ini berisi "Ada interaksi yang signifikan antara pendekatan latihan dan koordinasi mata tangan dengan ketepatan shooting dalam permainan bola basket". Berdasarkan hasil analisis Two Way Anova pada data interaksi pendekatan dengan koordinasi mata tangan diperoleh nilai $\mathrm{F}$ hitung sebesar 4,878 dengan nilai signifikansi sebesar 0,042. Oleh karena nilai signifikansi sebesar 0,042 lebih kecil dari 0,05 ( $\mathrm{p}<0,05)$, maka dapat disimpulkan ada interaksi yang signifikan antara pendekatan latihan dan koordinasi mata tangan dengan ketepatan shooting dalam permainan bola basket, 
sehingga hipotesis ketiga penelitian ini dapat diterima.

Interaksi antara pendekatan latihan dan koordinasi mata tangan dengan ketepatan shooting dalam permainan bola basket dapat dilihat pada Gambar 2. Berdasarkan pada Gambar 2 diketahui terdapat interaksi antara pendekatan latihan dan koordinasi mata tangan. Perpotongan garis pada grafik menunjukkan interaksi antara keduanya dengan titik pendekatan latihan metode taktis dengan koordinasi mata tinggi, dimana interaksi antara keduanya merupakan kombinasi yang paling efektif untuk mengingkatkan ketepatan shooting dalam permainan bola basket.

\section{Uji Lanjut Tukey}

Uji lanjut digunakan untuk mengetahui secara lebih mendalam dan detail perbedaan antara masing-masing kelompok perlakuan. Uji lanjut yang digunakan dalam penelitian ini mengguakan uji Tukey. Berdasarkan hasil uji Tukey pada Tabel 6 dapat diketahui kelompok yang diberi perlakuan pendekatan latihan teknis dengan koordinasi tinggi berbeda signifikan dengan kelompok yang diberi perlakuan pendekatan latihan teknis dengan koordinasi mata tangan rendah.

Berdasarkan penjelasan Tabel 6 diperoleh nilai dari perlakuan pendekaan latihan teknis dengan koordinasi mata tangan rendah yaitu $(p=0,002)$ dengan perbedaan nilai rerata sebesar 4,20 Kelompok taktis dengan koordinasi tinggi juga berbeda signifikan dengan kelompok yang diberi perlakuan teknis dengan koordinasi mata tangan rendah $(p=0,001)$ dengan perbedaan nilai rerata sebesar 6,00. Kelompok taktis dengan koordinasi mata tangan rendah juga berbeda signifikan dengan kelompok taktis dengan koordinasi mata tangan rendah $(p=0,002)$ dengan perbedaan nilai rerata sebesar 5,80 .

Pada ketiga kelompok yaitu teknis-koordinasi tinggi, taktis-koordinasi-rendah dan taktiskoordinasi tinggi menunjukkan hasil yang tidak berbeda signifikan $(p>0,05)$. Walaupun demikian dari ketiga kelompok tersebut, perlakuan yang paling baik dalam meningkatkan kemampuan shooting dalam permainan bola basket adalah kelompok yang diberikan perlakuan pendekatan latihan taktis dengan koordinasi mata tangan tinggi.

\section{SIMPULAN}

Berdasarkan hasil analisis data dan pembahasan yang telah dilakukan, kesimpulan penelitian ini adalah sebagai berikut: (1) Ada perbedaan pengaruh yang signifikan antara pendekatan latihan teknis, dan pendekatan latihan taktis terhadap ketepatan shooting bola basket pada peserta ekstrakurikuler di SMP Negeri 1 Sumpiuh dan SMP Negeri 2 Sumpiuh $(p=0,001)$. Pendekatan latihan taktis lebih tinggi (baik) dibandingkan dengan pendekatan latihan teknis. (2) Ada perbedaan pengaruh yang signifikan antara kemampuan motorik koordinasi mata tangan tinggi dan kordinasi mata tangan rendah terhadap ketepatan shooting bola basket pada peserta ekstrakurikuler di SMP Negeri 1 Sumpiuh dan SMP Negeri 2 Sumpiuh ( $p=0,027)$. Siswa dengan koordinasi mata tangan tinggi lebih tinggi (baik) dibandingkan dengan siswa dengan koordinasi mata tangan rendah. (3) Ada interaksi yang signifikan antara pendekatan latihan (pendekatan teknis, dan pendekatan taktis) dan koordinasi mata tangan (tinggi dan rendah) terhadap ketepatan shooting bola basket pada peserta ekstrakurikuler di SMP Negeri 1 Sumpiuh dan SMP Negeri 2 Sumpiuh $(p=0,042)$. Dengan demikian dapat disimpulkan bahwa ketepatan shooting bola basket pada peserta ekstrakurikuler di SMP Negeri 1 Sumpiuh dan SMP Negeri 2 Sumpiuh dipengaruhi oleh pendekatan latihan (teknis dan taktis) dan koordinasi mata tangan (tinggi dan rendah).

\section{DAFTAR PUSTAKA}

Departemen Pendidikan dan Kebudayaan Republik Indonesia. (1994). Petunjuk pelaksanaan kegiatan ekstrakurikuler. Jakarta: Departemen Pendidikan dan Kebudayaan.

Husdarta, H. J. S. (2011). Manajemen pendidikan jasmani. Bandung: Alfabeta.

Jatmika, H. M. (2005). Pemanfaatan media visual dalam menunjang pembelajaran pendidikan jasmani di sekolah dasar. Jurnal Pendidikan Jasmani Indonesia, 3(1).

https://doi.org/10.21831/JPJI.V3I1.6176

Mahardika, W. (2014). Pedagogi dalam olahraga bola basket. Jurnal Ilmiah Spirit, 14(3). Retrieved from http://ejournal.utp.ac.id/index.php/JIS/arti cle/view/279

Rachman, H. A. (2009). Dimensi kecakapan hidup (life skill) dalam pembelajaran pendidikan jasmani. Jurnal Pendidikan Jasmani Indonesia, 6(2). https://doi.org/10.21831/JPJI.V6I2.437 
Jurnal Keolahragaan 6 (2), 2018 - 109

Desi Adityo Hermawan, Hari Amirullah Rachman

Sagala, S. (2009). Kemampuan profesional guru dan tenaga kependidikan. Bandung: Alfabeta.

Subroto, T. (2009). Permainan besar (bola voli dan sepakbola). Jakarta: Universitas Terbuka.

Supriyanto, M. H. (2013). Pengaruh latihan koordinasi mata dan tangan dengan cara passing bola ke atas terhadap hasil belajar passng bawah bolavoli studi pada siswa SMA Assa'adah Bungah Gresik. Jurnal Pendidikan Olahraga Dan Kesehatan, 1(3). Retrieved from http://jurnalmahasiswa.unesa.ac.id/index. php/jurnal-pendidikanjasmani/article/view/4687

Wissel, H. (2011). Basketball: Steps to success. Human Kinetics Publishers. 